\title{
PENGARUH KOMBINASI TITIK LOKAL DAN YNSA TERHADAP PENURUNAN DERAJAT NYERI PADA PASIEN NYERI PINGGANG (LOW BACK PAIN)
}

\author{
Sri Yatmihatun*1, Sholichan Badri' ${ }^{2}$, Suwaji Handaru Wardoyo ${ }^{3}$ \\ Poltekkes Kemenkes Surakarta Jurusan Akupunktur
}

\begin{abstract}
Background: Low Back Pain is a common disorder involving the muscles, nerves and spine. The use of combination acupuncture, namely the local point and Yamamoto News Scalp Acupuncture (YNSA) is expected to accelerate the decrease in pain in patients with Low Back Pain. Methods: This study is used 45 respondents divided into 3 treatment groups, namely 1) Local point acupuncture therapy group, 2) Yamamoto News Scalp Acupuncture acupuncture therapy group, and 3) Local point combination with Yamamoto News Scalp Acupuncture therapy group. This research was conducted in the working area of the Ngemplak Community Health Center, Boyolali from January 2017 to September 2017. Measurement of pain using Visual Analog Scale (VAS). Results: The evaluation results showed that the respondent's data is normally distributed and homogeneous. ANOVA test showed there was a significant relationship between the local point acupuncture therapy group, Yamamoto News Scalp Acupuncture (YNSA) and Combination. The F value in this study is smaller than $\alpha(0.05)$. The T test showed that local acupuncture therapy is more effective than Yamamoto acupuncture therapy. News Scalp Acupuncture, and point combination acupuncture therapy are more effective than local points. Conclusion: Therfore it is the first report that proved the better method of combination (Local Point and YNSA) for reducing LBP quickly.
\end{abstract}

Keywords: Acupuncture, Low Back Pain, Local Point, YNSA

\section{PENDAHULUAN}

Low Back Pain (LBP) adalah gangguan umum nyeri pinggang yang melibatkan otot-otot, saraf, dan tulang belakang. Nyeri dapat bervariasi dari nyeri tumpul konstan kusam hingga nyeri tajam yang tiba-tiba. Gejala nyeri pinggang biasanya membaik dalam beberapa minggu dari pertama dirasakan, dengan $40-90 \%$ orang benarbenar lebih baik dengan enam minggu (Mardjono dan Sidharta, 2008).

Angka kejadian Low Back Pain hampir sama pada semua populasi masyarakat diseluruh dunia, baik di negara maju maupun di negara berkembang. Diperkirakan 1,6\% sampai $43 \%$ dari seluruh populasi masyarakat yang bekerja (Kumar, 2011). Penelitian yang dilakukan Kelompok Studi Nyeri
PERDOSSI melaporkan bahwa jumlah penderita nyeri sebanyak 4.456 orang (25\% dari total kunjungan), dengan 1.598 orang $(35,86 \%)$ adalah penderita Low Back Pain (Sudarmanto, 2008). Akupunktur telah digunakan secara luas sebagai metode untuk mengobati Low Back Pain (Baldry, Thompson, dan John, 2005), serta efektif untuk menghilangkan nyeri dan peningkatan fungsional pada Low Back Pain (Shin et al, 2011).

Penatalaksanaan terapi akupunktur untuk kasus Low Back Pain dapat menggunakan banyak prinsip, mulai dari penatalaksanaan terapi berdasarkan diferensiasi sindrom, berdasarkan meridian yang terkena, dan berdasarkan titik simtomatis. Terapi dapat juga ditambahkan mikro akupunktur seperti 
Ear Acupuncture, Hand and Foot micro acupuncture, abdominal acupuncture, dan Yamamoto New Scalp Acupuncture (YNSA) (Bai-Xinghua, 1996). Penatalaksanaan terapi pada penelitian ini menggunakan titik lokal (simtomatis) dan mikro akupunktur (YNSA). Aplikasi klinis penggunaan YNSA menunjukkan efek segera dan tahan lama pada pasien dengan gangguan alat gerak, seperti: sindrom nyeri, stroke kronis, dan Parkinson's (Schockert, 2011). Berdasarkan hal diatas, maka peneliti tertarik untuk melakukan penelitian penggunaan metode titik lokal dan titik YNSA dapat mempercepat penatalaksanan penurunan nyeri pada Low Back Pain.

\section{METODE PENELITIAN}

Penelitian ini dilaksanakan di Wilayah Kerja Puskesmas Ngemplak Boyolali dan dilaksanakan mulai Januari 2017 sampai September 2017. Subyek penelitian sebanyak 45 probadus yang terbagi menjadi 3 kelompok perlakuan, yaitu kelompok titik Lokal, kelompok titik YNSA, dan kelompok Kombinasi [titik Lokal dan titik YNSA]. Masingmasing kelompok perlakuan terdiri atas 15 probandus. Pengolahan data Uji statistik pada penelitian ini menggunakan uji Anova dilanjutkan uji $\mathrm{T}$ dengan menggunakan SAS 9.3.

\section{HASIL PENELITIAN}

Data kelompok perlakuan pemberian terapi akupunktur pada titik lokal, titik YNSA dan titik Kombinasi baik data sebelum terapi dan sesudah terapi mempunyai sebaran normal. Pada tabel 1 , Nilai F lebih kecil dari $\alpha$ (0.05), ini menunjukkan bahwa ada perbedaan efek intervensi diantara terapi akupunktur pada titik Lokal, titik YNSA, dan titik Kombinasi [titik lokal dan titik YNSA] dalam menurunkan nyeri pinggang bawah (Low Back Pain).

Tabel 1. Uji Anova

\begin{tabular}{lccccc}
\hline Sumber & DF & Jumlah Kuadrat & Mean Kuadrat & Nilai F & Pr $>$ F \\
\hline Model & 2 & 11.511 & 5.76 & 3.18 & 0.05 \\
Kesalahan & 42 & 76.13 & 1.813 & & \\
Koreksi total & 44 & 87.64 & & & \\
\hline \multicolumn{1}{c}{ Untuk } & mengetahui & apakah ada & signifikan antara kelompok akupunktur \\
perbedaan penurunan nyeri antar & pada titik lokal, kelompok akupunktur \\
kelompok menggunakan uji T. Tabel 2 & $\begin{array}{l}\text { titik YNSA, dan kelompok akupunktur } \\
\text { menunjukkan bahwa ada perbedaan }\end{array}$ & $\begin{array}{l}\text { dengan kombinasi [titik lokal dan } \\
\text { penurunan nyeri pinggang bawah secara }\end{array}$ & YNSA].
\end{tabular}

Tabel 2. Nilai Pengelompokan Terapi

\begin{tabular}{cccc}
\hline Uji-T & Mean & N & Kelompok \\
\hline A & 0.60 & 15 & Kombinasi (Lokal dan YNSA) \\
a,b & 1.20 & 15 & Lokal \\
B & 1.80 & 15 & YNSA
\end{tabular}

Hasil nilai pengelompokan terapi menunjukkan bahwa nilai mean terapi akupunktur Kombinasi [titik Lokal dantitik YNSA] paling kecil dengan nilai 0.60 yang memiliki arti bahwa terapi kombinasi paling efektif jika dibandingkan dengan terapi akupunktur titik lokal, dan terapi titik YNSA. 



\section{PEMBAHASAN}

1. Pengaruh Terapi Akupunktur pada Titik Lokal Terhadap Penurunan Nyeri Pinggang Bawah.

Terapi akupunktur menggunakan titik Lokal efektif dan signifikan untuk menurunkan nyeri pinggang bawah. Hal ini disebabkan oleh penusukan titik akupunktur pada titik Lokal dapat mempengaruhi jalur saraf nosiseptif, proprioseptif dan otonom. Terapi akupunktur dapat meningkatkan enkephalin dan dinorfin pada area lokal disekitar pinggang dan sekaligus berpengaruh segmental untuk mengirimkan impuls ke otak tengah sehingga dapat meningkatkan endorphin pada hypothalamus pituitary. Aliran enkephalin di otak tengah juga dapat menstimulasi keluarnya monoamine, serotonin dan norepinefrin di pinggang bawah sehingga dapat menghambat nyeri, termasuk juga nyeri muskuloskeletal (Audette dan Ryan, 2004).

Taghanaki et al., (2014) melaporkan bahwa terapi akupunktur yang ditambah dengan penusukan titik pertemuan 8 meridian dan titik berdasarkan jam organ dapat meningkatkan efikasi kesembuhan pasien yang mengalami LBP kronik. Mori et al. (2013) menambahkan bahwa terapi akupunktur selain dapat menurunkan nilai VAS juga dapat meningkatkan jumlah limfosit dan granulosit pada penderita nyeri bahu, punggung bawah dan nyeri lutut. Widowati (2017) melaporkan bahwa terapi akupunktur dengan kombinasi inframerah efektif menurunkan nyeri muskuloskeletal pada usia lanjut (menurunkan nilai mean dan SD).
2. Pengaruh Terapi Akupunktur YNSA Terhadap Penurunan Nyeri Pinggang Bawah.

Terapi

akupunktur menggunakan YNSA efektif dan signifikan untuk menurunkan nyeri pinggang bawah. YNSA ini bekerja melalui sistem syaraf pusat. Akupunktur pada YNSA mempengaruhi peningkatan aktivitas pada bagian Cortical dan Subcortical: Thalamus, lateral frontal-und dorsolateral prefrontal cortex (DLPFC), insula, medial dan ventromedial prefrontal cortex, posterior cingulate cortex (PCC), cerebellum, basal ganglia, dan periaqueductal grey (PAG). Hasil penelitian mencatat aktivitas pada nosiseptif (thalamus, insula, DLPFC, PAG), area pusat motor (cerebellum, basal ganglia), dan jaringan atensi. Perubahan yang sesuai dalam aktivasi sistem nosiseptif merupakan efek langsung dari YNSA (Schockert, 2011; Yamamotodan Helen, 2010).

Pada penelitian ini terapi menggunakan titik YNSA memiliki nilai mean lebih besar jika dibandingkan dengan terapi menggunakan titik Lokal pada kasus penurunan nyeri pinggang bawah. Ini artinya penggunaan titik Lokal lebih efektif dalam menurunkan nyeri pinggang bawah (LPB) dari pada menggunakan titik YNSA. Walaupun demikian, penggunaan titik YNSA tetap mempunyai nilai positif, diantaranya 1) lebih mudah untuk dipelajari dan lebih sistematis dan 2) terapi menggunakan titik YNSA lebih dapat diaplikasikan kepada pasien karena lokasinya yang mudah dijangkau dan lebih fleksibel. 
3. Lokal dan YNSA Terhadap Penurunan Nyeri Pinggang.

Hasil penelitian ini menunjukkan bahwa terapi kombinasi (titik lokal dan YNSA) paling efektif menurunkan nyeri Low Back Pain (LBP) terapi akupunktur titik lokal dan terapi akupunktur titik YNSA. Terapi akupunktur Kombinasi [titik lokal dan YNSA] memiliki efek ganda dalam menurunkan nyeri pinggang.

Terapi

akupunktur

kombinasi bekerja melalui empat domain, yaitu: 1) reaksi inflamasi lokal, 2) transduksi interseluler meridian, 3) refleks kutaneosomatoviscera, dan 4) transmisi neural ke otak (neuro akupunktur). Reaksi inflamasi lokal ditandai dengan adanya vasodilatasi. Transduksi interseluler meridian ditandai dengan pertukaran ion listrik di jalur meridian. Refleks kutaneosomatoviscera ditandai dengan mengaktifkan sistem modulasi nyeri dengan cara menekan transmisi dan persepsi dari rangsangan nyeri pada level yang berbeda pada sistem saraf pusat. Kombinasi terapi ini sangat baik dalam penurunan nyeri muskuloskeletal (Gellman, 2006; Saputra dan Sudirman, 2009 dan Yun et al., 2005).

\section{KESIMPULAN DAN SARAN}

Terapi akupunktur menggunakan Kombinasi titik akupunktur Lokal dan titik Yamamoto News Scalp Acupuncture (YNSA)paling efektif dalam menurunkan nyeri pinggang dibandingkan menggunakan terapi akupunktur titik Lokal atau titik
Yamamoto News Scalp Acupuncture (YNSA).

Perlu diadakan penelitian lebih lanjut untuk mengetahui mekanisme fisiologi dan hormon yang dikeluarkan saat dilakukan terapi akupunktur pada kasus tersebut, selain itu perlu juga dilakukan penelitian lebih mendalam dan mendetail dengan jumlah pasien LBP yang lebih besar pada model terapi tersebut.

\section{DAFTAR RUJUKAN}

Audette, J. F., and Ryan, A. H. 2004. The role of acupuncture in pain management.15, 749-772. http://doi.org/10.1016/j.pmr.2004. 03.009

Bai-Xinghua. 1996. Acupuncture in Clinical Practice. Beijing: Butterworth Heinemann.

Baldry, P.E., Thompson, John W. 2005. Acupuncture, Trigger Points and Musculoskeletal Pain:A Scientific approach to acupuncture for use by doctors and physiotherapists in the diagnosis and management of myofascial trigger point pain. Brookline: Elsevier

Gellman, H. 2006. Acupuncture Treatment for Musculoskeletal Pain. Florida: Taylor and Francis.

Kumar, M. 2011. Epidemiology Pathophysiology and Symptomatic Treatment of Sciatica. A Review International Journal of Pharmaceutical \& Biological Archives; 2(4); 1050-1061.

Mardjono., Sidharta. 2008. Neurologi Klinis Dalam Praktek Umum. Jakarta: Dian Rakyat.

Mori, H., Kuge, H., Tanaka, T. H., Taniwaki, E., \& Hanyu, K. 2013. Effects of acupuncture treatment on natural killer cell activity, pulse rate , and pain reduction for older adults: an uncontrolled, 
observational study. Journal of IntegrativeMedicine. 11(2), 101105.

http://doi.org/10.3736/jintegrmed2 013012

Murti, B. 2013. Desain dan Ukuran Sampel untuk Penelitian Kuantitatif dan Kualitatif di Bidang Kesehatan. Yogyakarta: Gajah Mada University Press.

Price, Sylvia. 2006. Patofisiologi Konsep Klinis Proses-Proses Penyakit. Jakarta: Buku Kedokteran EGC

Saputra, K., dan Sudirman, S. 2009. Akupunktur untuk Nyeri dengan pendekatan Neurosain. Jakarta: Sagung Seto.

Schockert, Thomas. 2011. Yamamoto New Scalp Acupuncture (YNSA): Development, principles, Safety, Effectiveness and Clinical Applications, Acupuncture Clinical Practice, Praticular Techniques and Special Issues, Prof. Marcelo Saad (Ed.), ISBN: 978-963-307-630-0, InTech

Shi Xuemin. 2007. Acupuncture and Moxibustion. Beijing: Higher Education Press.

Sudarmanto, Y.A. 2008. Perbedaan Efek Analgesia Akupunktur AntaraMetoda Segmental Dan Non Segmental Pada NyeriPunggung Bawah. Tesis. Universitas sebelas Maret Surakarta.

ARandomize42Controlled Trial of Acupuncture for Chronic LowBack Pain. AlternativeTherapies, 20(June), 13-20

Widowati, R. 2017. Efektifitas Terapi Akupunktur dan Inframerah dalam Menurunkan Nyeri Muskuloskeletal pada Lanjut Usia. Tesis. Universitas Sebelas Maret Surakarta.
Yamamoto, Toshikatsu., Helen, Yamamoto. 2010. Yamamoto Margaret Michiko: Yamamoto New Scalp Acupuncture (YNSA). Miyazaki Minami Printing Co., Ltd.

Yun, T. M., Mila, M., and Zhang, H. C. 2005. Biomedical Acupuncture for Pain Management. Philadelphia: Elsavier Churchill Livingstone 